\title{
The Role of Promotion Strategies in Increasing the Sales Volume of Regional Specialty Foods in Nampes Hamlet, Baturetno Village, Singosari Malang
}

Eka Yuliati, Dewi Urip Wahyuni

To Link this Article: http://dx.doi.org/10.6007/IJARBSS/v12-i1/12093

DOI:10.6007/IJARBSS/v12-i1/12093

Received: 18 November 2021, Revised: 20 December 2021, Accepted: 11 January 2022

Published Online: 27 January 2022

In-Text Citation: (Yuliati \& Wahyuni, 2022)

To Cite this Article: Yuliati, E., \& Wahyuni, D. U. (2022). The Role of Promotion Strategies in Increasing the Sales Volume of Regional Specialty Foods in Nampes Hamlet, Baturetno Village, Singosari Malang. International Journal of Academic Research in Business and Social Sciences, 12(1), 2257-2269.

Copyright: (c) 2022 The Author(s)

Published by Human Resource Management Academic Research Society (www.hrmars.com)

This article is published under the Creative Commons Attribution (CC BY 4.0) license. Anyone may reproduce, distribute, translate and create derivative works of this article (for both commercial and non0-commercial purposes), subject to full attribution to the original publication and authors. The full terms of this license may be seen

at: http://creativecommons.org/licences/by/4.0/legalcode

Vol. 12, No. 1, 2022, Pg. 2257- 2269

Full Terms \& Conditions of access and use can be found at http://hrmars.com/index.php/pages/detail/publication-ethics 


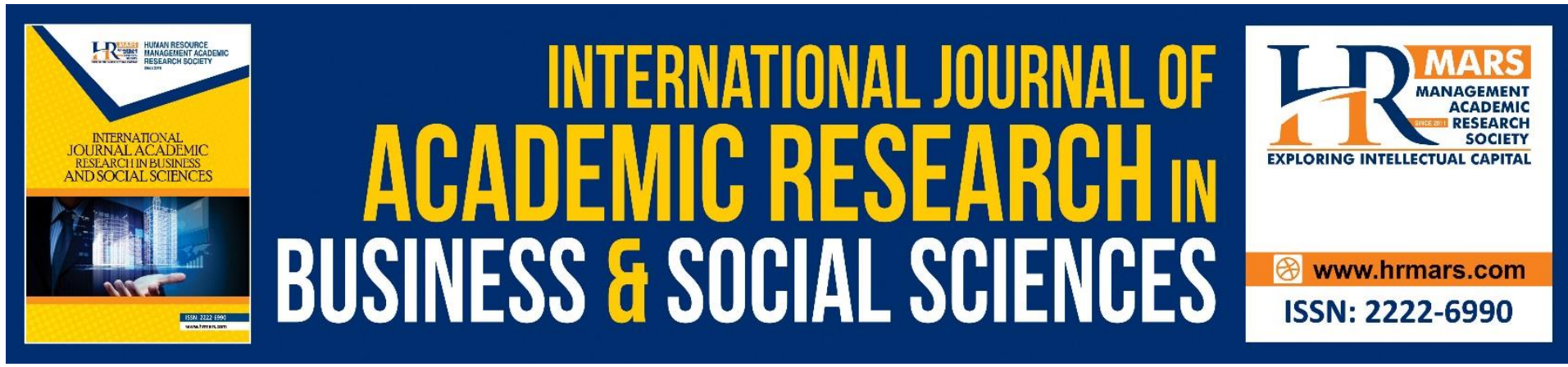

\title{
The Role of Promotion Strategies in Increasing the Sales Volume of Regional Specialty Foods in Nampes Hamlet, Baturetno Village, Singosari Malang
}

\author{
Eka Yuliati, Dewi Urip Wahyuni \\ Indonesia School of Economics (STIESIA) Surabaya, Indonesia \\ Email : ekayuliati@stiesia.ac.id, dewiuripwahyuni@stiesia.ac.id
}

\begin{abstract}
In accordance with the level of human needs, primary needs consisting of clothing, food and housing have always been the main thing in choosing a business. Based on this, it is not surprising that the food business has an increasing trend. An increase in demand will lead to an increase in food supply. This is in accordance with the law of supply and demand. There are various food businesses, including restaurant businesses and popular catering businesses (cafes, coffee shops, bakeries and steak houses). Likewise with the types of food sold, some are modern and some are a characteristic of an area. In the field of marketing, the most difficult condition is to keep consumers in order to always buy products from the same seller. To address this problem, one of the methods that must be carried out by your company is to implement a good promotional strategy. Given that one of the purposes of promotion is to remind consumers that the product is still available. Besides being able to serve as a reminder for consumers, promotional strategies are also expected to increase sales volume. The strategy applied can be in the form of a promotion mix consisting of: advertising, sales management, personal selling, sales promotion and publicity.
\end{abstract}

Keywords: Promotion Strategy, Marketing, Selling

\section{Introduction}

Competition in the business world is getting tighter, making companies try to find a fast and appropriate strategy in marketing their products. In the era of globalization, companies must be able to act and act quickly and appropriately in the face of competition in a business environment that moves very dynamically and is full of uncertainty. Therefore, every company is required to compete competitively in terms of business strategies to achieve company goals and understand what is happening in the market and what consumers want. Every company was founded with a specific purpose so that it can survive and thrive. One of the company's goals is to increase the level of company profits or profits. The level of profit can be maintained if the company can maintain and increase its sales, one of which is through efforts to find and foster subscriptions. Marketing activities are a very important and influential factor for the company, therefore the marketing department must have a solid 
strategy in seeing the opportunities or opportunities that exist, so that the company's position in the market can be maintained and at the same time can be improved. A consumer-oriented marketing strategy is the best way a company can do it.

Companies in this case not only sell products, but also must understand what consumers want so that it will affect consumer purchasing decisions. Currently, regional specialties are being promoted by each region. Especially with yesterday's pandemic conditions that had lowered the foundations of the economy. There are many types of regional specialties that are currently starting to be glimpsed by local consumers and foreign consumers, this is evident from the exporters in our country which are starting to show signs of increasing. The types of food typical of the area can be in the form of chips, types of crackers and also other snacks. The food business never dies, this is probably what keeps this business afloat and is a favorite business choice for large and small scale businesses. This regional specialty food business has mushroomed, along with the ability of each producer to market it. The trend of regional specialties that continue to grow and adapt to the times also affects the food business increasingly rampant.

In the midst of business competition, regional specialty food businesses must be able to compete by providing different values in the eyes of consumers and paying attention to the factors that influence consumer purchasing decisions in order to survive in the midst of hectic competition and to increase sales turnover.

Companies must determine product development strategies and designs that can meet consumer needs by innovating or following current market trends. Many things must be prepared before determining the right strategy for the company, one of the first steps is to recognize consumer behavior and obtain information related to their behavior. In an effort to influence the market to make purchasing decisions, promotional activities (promotional mix) are a better strategy combination, and are entirely planned to achieve sales objectives. One of the variables of the promotion mix is advertising.

The standard definition of advertising contains six elements. First, advertising is a paid form of communication, although some forms of advertising such as public service advertisements usually use a free dedicated space, or if you have to pay a relatively small amount compared to commercial advertising. Second, in addition to the message conveyed must be paid for, in the advertisement there is also a sponsor identification process. Advertisements not only display messages about the greatness of the products offered, but also convey information to consumers about who the companies that produce the products offered are. Third, advertising has the main purpose of persuading or influencing consumers to do something. In advertising, messages are designed in such a way as to persuade or influence consumers. Fourth, advertising requires mass media as a medium for delivering messages to the target audience. The media can be newspapers, radio, television, posters and magazines. The use of mass media makes advertising categorized as mass communication, so that advertising is nonpersonal. This non-personal nature is the fifth element in the definition of advertising. The sixth or final element is the audience. In advertising design, the group of consumers who will be the target of the message must be clearly defined. Without a clear identification of the audience, the message conveyed in the advertisement will not be effective. On the other hand, to be able to compete with global products, many strategies are carried out by the company, including promotion.

Promotion is used to support various other marketing strategies (product strategy, pricing strategy, and distribution strategy). Promotion will accelerate the delivery of marketing strategies to consumers. Without promotion, this strategy will be difficult to reach 
consumers. The discount strategy will not be known by consumers without promotion. Quality products at fair prices will be difficult to sell if they are not promoted so that consumers know their existence. Product differentiation will not be well known by consumers if it is not promoted.

In this case, regional specialties do not maximize their promotion, they only do a few small items from the promotion, namely discounts. According to an initial survey conducted by researchers based on interviews with 10 prospective consumers who are around the regional specialty food business, that the promotions that have been carried out by this regional specialty food business are deemed less emotionally attractive to consumers, this is due to the lack of incessant promotions carried out by the local food industry. local food business. If the promotion is intense, consumers who were previously not interested in buying a product will become interested and try the product so that consumers make purchases at the regional specialty food business. Seeing the opportunities that exist, marketers certainly want to get maximum results with this promotional strategy. It is hoped that the promotional strategy carried out by the marketers of a company can introduce a new product or remind consumers about existing products and increase sales levels.

Considering the limitation of the ability, time, and research costs, the problems studied are limited so that the research carried out is more focused, so this research only examines the problems that exist in the role of promotion strategies in increasing sales volume.

\section{Literature Review}

The references supporting the present study were broadly divided into: first, promotion, which also relates to the theory of buying interest; second, buying decision, References were taken from journals on related topics, books, regulations and program documents as well as relevant decision-making theory

\section{Promotion}

\section{Definition of Promotion}

Sales promotion is an incentive that sooner or later moves people to buy or get, generally in the short term, either in the form of money or goods - a product or service. persuading, and or reminding the target market of the company and its products to be willing to accept, buy and be loyal to the products offered by the company concerned, Tjiptono (2001: 219). While Sistaningrum (2002: 98) reveals the meaning of promotion is an effort or company activity in influencing "actual consumers" and "potential consumers" so that they want to make purchases of the products offered, currently or in the future. Actual consumers are consumers who immediately buy the products offered at the time or shortly after the promotion of the product is launched by the company. And potential consumers are consumers who are interested in making purchases of the products offered by the company in the future.

Promotional Purpose

The purpose of the company doing promotions according to Tjiptono (2001:221) is to inform (informing), influence and persuade (persuading) and remind (reminding) customers about the company and its marketing mix. Sistaningrum (2002: 98) explains that the purpose of promotion is four things, namely introducing oneself, persuading, modifying and shaping behavior and reminding again about the product and the company concerned. In principle, the two are the same, that is, they both explain that if the product is new, it is necessary to introduce or inform consumers that there is currently a new product that is not inferior to the old product. After consumers know a new product, it is hoped that consumers will be 
influenced and persuaded to switch to that product. And in the end, the company just reminded that the product is still good for consumption.

In carrying out promotions to be effective, it is necessary to have a promotional mix, namely the optimal combination of various types of activities or the selection of the most effective types of promotional activities in increasing sales. There are four types of promotional activities, including: (Kotler, 2001: 98-100) 1) Advertising, which is a form of non-personal promotion using various media aimed at stimulating purchases. 2) Face-to-face selling (Personal Selling), namely a form of personal promotion with oral presentations in a conversation with potential buyers aimed at stimulating purchases. 3) Publicity, which is a form of non-personal promotion of certain services or business entities by reviewing information/news about them (generally scientific). 4) Sales promotion, which is a form of promotion outside the three forms. above which is intended to stimulate purchases. Types of sales promotions include rebates, coupons, or sweepstakes, ongoing programs, premium giving, rebates and free samples. 5) Direct marketing, which is a form of personal selling directly aimed at to influence consumer purchases

Grouping Based on Objectives Promotions carried out by sellers can be grouped based on the objectives to be achieved. The groupings are as follows: 1) Customer promotion, namely promotions that aim to encourage or stimulate customers to buy. 2) Trade promotions, namely sales promotions that aim to stimulate or encourage wholesalers, retailers, exporters and importers to trade goods/services from sponsors. 3) Sales-force promotion, namely sales promotion that aims to motivate the sales force. 4) Business promotion, namely sales promotion that aims to acquire new customers, maintain contractual relationships with customers, introduce new products, sell more. because $b$ to old customers and educating customers. But what is clear is that whatever the type of needs that will be programmed to be influenced, it remains to plan how the company can exist and develop. Especially if the company has more than one product line. The number of attacks that come from competitors. Buying Interest

Understanding buying interest According to the Big Indonesian Dictionary (2002: 744), buying interest is a high-minded tendency towards something. According to the Big Indonesian Dictionary (2002: 126), buying is getting something with heavy sacrifices (effort, etc.). According to Simamora (2002: 131), interest is something personal and related to attitudes, individuals who are interested in an object will have the power or encouragement to perform a series of behaviors to approach or get the object. According to Kotler and Keller (2003: 186) , the consumer may also form an intention to buy the most preferred brand which means that consumers have a desire to buy a product based on a brand. According to Kotler, Bowen, \& Makens (1999: 156), the alternative evaluation process and in the evaluation process, a person will make a series of choices regarding the product to be purchased on the basis of brand and interest.

Factors that influence buying interest Swastha \& Irawan (2001) suggest factors that influence buying interest related to feelings and emotions, if someone feels happy and satisfied in buying goods or services then it will strengthen buying interest, dissatisfaction usually eliminates interest. Super \& Crites (Lidyawatie, 1998) explains that there are several factors regarding buying interest

1) Job differences, meaning that with differences in one's work it can be estimated that interest in the level of work he wants to achieve, the activities carried out, the use of his free time, and so on. 
2) Socio-economic differences, meaning that someone who has a high socioeconomic status will more easily achieve what he or she wants than someone with a low socioeconomic status. 3) Different hobbies or hobbies, meaning how a person uses his free time

4) Gender differences, meaning that the ages of children, adolescents, adults and parents will have different interests in an object, object's activity and a person. (http://jurnalsdm.blogspot.com).

c. Future Intention Re-purchase (repeat purchase) according to Peter / Olsen (2002) is a purchase activity that is carried out more than once or several times. Satisfaction obtained by a consumer, can encourage him to make a repeat purchase (repeat purchase). , be loyal to the product or loyal to the store where he bought the item so that consumers can tell good things to others. According to Schiffman \& Kanuk (2000) repurchase behavior is closely related to the concept of brand loyalty, where most companies support because this has a major contribution to good stability in the marketplace. Zeithalm et al (1996) emphasize that it is important to measure customer future intention to find out the desire of customers who remain loyal / leave an item/service. Consumers who feel happy and satisfied with the goods/services they have purchased will think about repurchasing the goods/services. Repeated purchases will make consumers loyal to an item / service (Band, 1991).

Buying decision.

a. Understanding Consumer Behavior

The definition of consumer behavior according to Basu Swastha is the activities of individuals who are directly involved in obtaining and using goods and services, including the decisionmaking process in the preparation and determination of these activities (Swasta, 1997: 10). This definition reveals two important things in consumer behavior, namely: 1) Direct actions or physical activities which all involve individuals assessing, obtaining and using economic services. 2) The decision-making process includes decisions that precede and accompany the above actions.

b. Consumer Behavior Model In an effort to understand consumer behavior, there are several models that can be used as a reference. Kotler and Armstrong (2006: 129), put forward a model of consumer behavior as shown in Figure 1

Purchase Decision Structure

The buying decision made by the buyer is actually a collection of a number of decisions. Each buying decision has a structure of seven components. These components will be discussed below in connection with the example of buying a small radio. 1) Decisions About Types of Products Consumers can make decisions to buy a radio or use the money for other purposes. In this case the company must focus its attention on people who are interested in buying radios and other alternatives they are considering. 2) Product Shape Decisions Consumers can make decisions to buy certain radio forms. These decisions involve size patterns, sound quality, patterns and so on. In this case the company must conduct marketing research to find out consumer preferences about the product in question in order to maximize the attractiveness of the brand. 3) Decisions About Brands. Consumers must make decisions about which brand to buy because each brand has its own differences. In this case the company must know how consumers choose a brand 4) Decisions About Sales Consumers must make decisions where the radio should be purchased. Whether in convenience stores, stationery stores, radio specialty stores, or other stores. In this case, manufacturers, wholesalers and retailers must know how consumers choose a particular seller. 


\section{Methods}

This research method includes observation, interviews and questionnaires. This study uses primary data and secondary data. Primary data were obtained through interviews, questionnaires and field observations. Samples of visitors to local specialties in Nampes hamlet, Baturetno Village, Singosari Malang were taken by accidental sampling method (Kusmayadi, 2004). Secondary data was obtained through the policy desk review of the Department of Cooperatives, MSMEs and Industry of Malang City along with information, the Women's Empowerment and Family Planning Agency of the East Java Provincial Government, the Community Empowerment and Family Planning Agency of Malang City Government news and discourse from the mass media related to the research topic.

Interviews were conducted by collecting information in structured questions posed to associations of local food traders in Nampes hamlet, Baturetno Village, Singosari Malang, most of whom were women.

\section{Analysis and Conclution Geographic Conditions}

Singosari District is one of 33 sub-districts in Malang Regency which has an area of 14,876 $\mathrm{Ha}$ with regional boundaries: To the north: Lawang District East: Jabung District South side: Blimbing District, Malang City and West side: Karangploso District. The participation of the population in regional development has a fairly strong bond in accordance with the place of residence and social characteristics of the community. The population of Singosari Subdistrict in 2019 was 177,115 people with the largest population in Banjararum Village, namely 17,084 people and the smallest population in Losari Village, which was 5,229 people.

The existence of Nampes hamlet, Baturetno village in Singosari sub-district, which is in the middle of the location causes residents to be close in any direction. This is a distinct advantage for the local community who want to distribute their products. In addition, the geographical condition of Singosari Malang, which is cool and tends to be cold, makes the surrounding community happy to eat snacks.

The merchant stalls in this village area do not look real yet, because most of them sell their wares on consignment and use Instagram stories and WhatsApp status and offer their wares by word of mouth. This is what makes one of the weaknesses of the typical food vendors in the city. We will see different views when we go to other cities, take the example of Kediri, which is famous for its yellow year and banana getuk. If we go to Jl.Pattimura in the city, the scenery along the road in that place will show the typical food of the area. On the side of the road, you will see stalls selling banana getuk, yellow tofu, typical Kediri sand crackers and much more. The condition has not been seen in Nampes hamlet, Singosari

According to the information I got when we visited this place, these merchants had never received assistance from either the local government or the central government. This can happen because they don't yet have a forum that can bridge their interests for this matter. Actually, the government through the Coordinator of the Community Self-Reliance Institution (BKM) in each output has funds for it, which is usually better known as PNPM and can be used for other fields. other activities, as long as these activities can support the improvement of welfare for the surrounding community. These fields include environmental, economic and social activities.

Based on field observations and interviews with one of the LKMK members, some of the obstacles and weaknesses experienced by traders in Nampes hamlet, Baturetno Singosari Kenjeran village, are as follows. First, the quality of human resources is low. Second, business 
management is run 'messy'. This means that business management is not based on proper management principles where business turnover and profits are managed in such a way as to support the business in the future. Third, the reluctance of traders to accept positive, useful and important input for the progress and future of their business. They are not open to new ideas and matters related to business management, especially the stimulation to innovate and create unique products.

The local food vendors in Nampes hamlet have an erratic average turnover per day. This condition is exacerbated by the COVID-19 outbreak, which has recently been a factor in many sectors experiencing a decline. Actually, with the taste of regional specialties that they have produced so far, they can already compete with other local products. Evidently, with the products they sell using a consignment system in which there are also products from other places. This regional specialty has a high turnover. On a different occasion, when we visited again and asked what principle was causing the sales volume of the traders to not increase. Most of them said that the promotions that had been carried out so far had not gone well. The data shows that the percentage of businesses engaged in agriculture is higher than trading businesses, including supermarkets/convenience stores. This data convincingly shows that the people in Nampes hamlet are indeed more interested in the agricultural business. This is also supported by their geographical environment.

Table 1

Number of Trading Businesses

\begin{tabular}{cc}
\hline DESCRIPTION & NUMBER \\
\hline Convenience store & 23 business units \\
Agriculture & 30 business units \\
Total & 53 business units \\
\hline
\end{tabular}

Source: Report of Profile Data Compilation of Kelurahan Baturetno Village, Kecamatan Singosari 2020

The success of promotional activities carried out by a company is not only determined by the amount of costs incurred by the company but is more influenced by how the company can convey the message it wants to convey so that it can be accepted by consumers and right on target as expected by the company. Companies need to pay attention to various things that influence the success of implementing promotions in promotional strategies. The thing that needs to be considered is the promotional mix consisting of several main variables including advertising (advertising), personal selling (personal selling), sales promotion (sales). promotion), and publicity (publicity). In order for the promotion to be carried out properly, the company must study the most suitable potential adaptations to the conditions of the company and consumers both internally and externally, so that these activities can run effectively and efficiently and on target. Of the four existing promotional mixes, only two things, namely personal selling and sales promotion, have been done by them, while the rest have not.

Another background related to this is that the traders in Nampes village lack the confidence to try new things and take a little risk. Instead, they prefer to imitate and follow in the footsteps of other traders. This is indicated by the lack of unique local commodities that are sourced from their habits. Most of the community's commodities are focused on processed tempeh which is used as tempeh chips. 
To overcome these obstacles, the main thing that must be accelerated is the implementation of an integrated promotional mix so that there is an increase in sales volume as desired. Besides that, it is also necessary to activate programs from relevant government agencies or other parties to guide the community in finding new business plans that are unique, creative and of sale value while still utilizing local resources. A synergistic program from the Agency for Community Empowerment and Family Planning, the Department of Culture and Tourism, and the Department of Marine Affairs and Fisheries, by cooperating with universities or other institutions, to further mobilize the economic potential of the community in Nampes hamlet, Baturetno Singosari village, Malang.

\section{Questionnaire Results}

We will present the results of the questionnaires that have been filled out by buyers of typical food from the Nampes hamlet, Baturetno village. This questionnaire was distributed when we visited their village. With the hope of getting the original respondents from the source. In the first group, the descriptions of respondents can be distinguished in terms of age, gender and occupation. For the second group, we describe the respondents in terms of housewives, employees, retirees and others. In the last classification, we focus on the problem of sales volume.

The questionnaire which was filled out by 30 respondents was divided into 2 categories of statements, the first related to the attractiveness of their typical food (10 items). The points in this section describe the implementation of the typical food taste values of the Nampes hamlet, Baturetno Singosari village, Malang (food color, food form, packaging, aroma, texture, crispness, ripeness,). Most of the respondents agree with the following statement. With regard to the first statement that regional specialties are interesting foods, 21 respondents strongly agree, 87 respondents agree and 12 respondents disagree. For the second statement that regional specialties are enjoyable food, 24 respondents strongly agree, 86 respondents agree, 8 respondents disagree and 2 respondents strongly disagree. To the third statement that regional specialties show the characteristics of an area, 16 respondents strongly agree, 77 respondents agree, 26 respondents disagree, and 1 respondent strongly disagrees. For the fourth statement that local snacks are interesting, 13 respondents strongly agree, 86 respondents agree, and 21 respondents disagree. For the fifth statement regarding recommending others to buy typical food in Nampes village, 30 respondents strongly agree, 79 respondents agree, 9 respondents disagree, and 2 respondents strongly disagree. Regarding the sixth statement about the attractiveness of regional specialty food packaging, 30 respondents strongly agree, 80 respondents agree, and 10 respondents disagree. For the seventh statement, regional specialties need to be managed properly, 16 respondents strongly disagree, 77 respondents agree, 25 respondents disagree, and 2 respondents strongly disagree. The eighth statement regarding the crispness of regional specialties needs to be maintained, 40 respondents strongly agree, 79 respondents agree, and 1 respondent disagrees. For the ninth statement that the Nampes hamlet community is friendly, 21 respondents strongly agree, 88 respondents agree, 9 respondents disagree, and 2 respondents strongly disagree. However, respondents also highlighted the weakness of regional specialties by doubting the quality of food hygiene, where 7 respondents strongly agreed, 47 respondents agreed, 56 respondents disagreed, and 10 respondents strongly disagreed.

The second category is statements related to traders in Nampes hamlet, Baturetno Singosari Malang district ( 7 items). Most of the respondents agreed with all statements related to the 
implementation of increased promotions for regional specialties, some even suggested that later local food vendors in this area could co-exist with ornamental flower sellers. There are findings that we have not discussed before, about the existence of many ornamental plant sellers in the village. Even the researchers also had time to buy the flowers, and it turned out that the plant seeds they sold were good. This is evidenced by the flourishing of these ornamental plants. These statements are related to the existence and performance of traders in Nampes hamlet, Baturetno Singosari village, Malang. For the first statement regarding the availability of traditional food with authentic taste and equipped with a neatly arranged dining area, 38 respondents strongly agree, 76 respondents agree, and 6 respondents disagree. For the second statement regarding the availability of interesting and unique souvenirs, 31 respondents strongly agree, 81 respondents agree, 7 respondents disagree, and 1 respondent strongly disagrees. For the third statement regarding the availability of souvenirs that have a unique texture, 39 respondents strongly agree, 80 respondents agree, and 1 respondent disagrees. Regarding the fourth statement that the traders in Nampes hamlet are well organized, 19 respondents strongly agree, 68 respondents agree, 30 respondents disagree, and 3 respondents strongly disagree. For the five statements that traders in Nampes hamlet are creative, 21 respondents strongly agree, 91 respondents agree, 6 respondents disagree, and 2 respondents strongly disagree. Regarding the sixth statement that traders in Nampes hamlet represent strong women, 30 respondents strongly agree, 77 respondents agree, 11 respondents disagree, and 2 respondents strongly disagree. For the seventh statement that the traders in Nampes hamlet are friendly, 21 respondents strongly agree, 88 respondents agree, 6 respondents disagree, and 5 respondents strongly disagree.

Opportunities to increase sales volume by maximizing promotional strategies are predicted to be successful and last a long time. In marketing their products so that these products can be known and in demand by consumers, companies need to use marketing mix tools. Marketing mix tools consist of advertising (advertising), sales management, personal selling (personal selling), sales promotion (sales promotion), and publicity (publicity). In order for the promotion to be carried out properly, it is necessary to have a special strategy in combining the four existing variables. Companies must be able to choose the most suitable variables with the capabilities and conditions of the company both internally and externally, so that these activities can run effectively. So it is clear that the relationship of the promotion mix is very closely related in marketing the product to the final consumer. Likewise, by increasing sales volume, it can be used as a measure for the company whether the products produced by the company sell well in the market. The right promotional strategy through the promotional mix is marked by more and more consumers who are interested in buying and using the company's products, sales margin will be boosted up. In other words, the success of promotional activities will have a direct impact on increasing sales volume. Promotional strategies will be able to have an influence on product sales, if the selection of promotion strategies is in accordance with product characteristics and several other factors, the promotional strategy will have a positive impact, namely increasing sales.

\section{Conclusions and Recommendations Conclusions}

The conclusions of this study are as follows:

1. Promotional mix consisting of advertising (advertising), sales management, personal selling (personal selling), sales promotion (sales promotion), and publicity (publicity) has not been 
carried out by all typical food traders in Nampwes hamlet, Baturetno Singosari village, Malang .

2. The entrepreneurial spirit and practice of the traders in Nampes hamlet, Baturetno Singosari village, Malang is carried out in a simple pattern, without a development design that provides direction for the progress of business scale.

3. The merchant association in Nampes hamlet, Batureto Singosari village, Malang, acts as a mediator between managers and traders to maintain good relations and partnerships.

4. The mentoring program and the development of promotional strategies as a way to increase sales volume and provide added value for their products in the form of regional specialties have not been carried out in a systematic and sustainable manner.

\section{Research Contribution}

One of the company's efforts in marketing its products is trying to get the right market share. This is because marketing can be used as a means to sell and distribute products to end consumers, including the regional specialty food company in Nampes hamlet, Maduratna village, Singosari district. Currently they are trying to market their products so that these products can be known and in demand by consumers so they need to use promotional mix tools, which consist of advertising (advertising), personal selling (personal selling), sales promotion (sales promotion), and publicity. (publicity). In order for the promotion to be carried out properly, it is necessary to have a special strategy in combining the four existing variables. Companies must be able to choose the most suitable variables with the capabilities and conditions of the company both internally and externally, so that these activities can run effectively and efficiently. So here it is clear that the relationship between the promotion mix is very closely related in marketing the product to the final consumer. If they are able to increase marketing to final consumers, an increase in sales volume will be realized. The right promotional strategy through the promotion mix is marked by the more consumers who are interested in buying and using the products issued by the company, the sales margin will be boosted up. In other words, the success of promotional activities will have a direct impact on increasing sales volume.

\section{Suggestion for Future Research}

For this reason, in order to further develop the regional specialty food business, there are several strategies that can be carried out, including (1) Optimizing the role of promotion in marketing and increasing sales volume (2) socializing the promotion mix program (3) Increasing the participation of government agencies in charge of curiosity. It is hoped that the publication of this journal will

can implement this strategy and the prospect of local food vendors will no longer experience difficulties in terms of increasing sales volume.

\section{Recommendation}

Some important recommendations to be followed up from this research are as follows:

1. It is necessary to develop and improve the quality of a systematic and continuous promotion strategy, which is focused on increasing sales volume

2. Typical food from Nampes hamlet, Baturetno Singosari village, there must be improvement in terms of quality, taste and packaging, this is intended so that they can compete with competitors. 


\section{References}

Alma, B. (2005). Manajemen Pemasaran dan Pamasaran Jasa. Bandung: CV Alfabeta.

Arikunto, S. (2013). Prosedur Penelitian: Suatu Pendekatan Praktik. Jakarta: Rineka Cipta.

Arjuna, W. S. (2014). Analisis Implementasi Strategi Promosi Dalam Menghadapi Persaingan (Kasus Pada Ajb Bumiputera 1912 Wilayah Pekanbaru). Jom FISIP Volume 1 No. 2, 1-12. Assauri, S. (2014). Manajemen Pemasaran.Jakarta: Rajawali Pers.

Berg, J. M., Tymoczko, J. L.,\&Stryer, L. (2009),p.108-109). Biochemistry. (5th.ed).WH Freeman. Bungin, B. (2011). Penelitian Kualitatif. Jakarta: Kencana Predana Media Group.

Lamb, C. W., Hair, J. F., \& McDaniel, C. (2001). Pemasaran (Jilid II). Jakarta: Salemba Empat Gitosudarmo.

Creswell, J. W. (2012). Research design Pendekatan kualitatif, Kuantitatif dan Mixed; Cetakan ke-2.Yogyakarta: Pustaka Pelajar.

Farida. (2015). Analisis Promosi Penjualan Dan Peningkatan Volume Penjualan Sepeda Motor Merk Yamaha Pada Cv. Sinar Utama Di Samarinda. Samarind.

Haruna, M. I. (2015). Department of Management Technology, Modibbo Adama University of Technology, Yola, Adamawa State, Nigeria. International Journal of British Journal of Marketing, Studies Vol.3, No.3, pp.71-88, June 2015.

Rohaeni, H. (2016). Peranan Promosi Melalui Personal Selling Terhadap Volume Penjualan, Jurnal Ecodemika (Jurnal Ekonomi, Manajemen dan Bisnis), Vol 4, No 2.

Indriyo. (2000). Manajemen Pemasaran.Yogyakarta: BPFE.

Jaya, R. D.,Desfitrina., \& Bassi, A.(2021).Peranan Strategi Promosi Dalam Meningkatkan Volume Penjualan Pada PT. Trans Retail Indonesia. Diploma thesis: Universitas Tamansiswa Palembang

Kasali, R. (1999). Manajemen Periklanan.Jakarta: PT Pustaka Utama Grafiti.

Kotler, P.(2002). Manajemen Pemasaran. (Jilid I). Jakarta: PT.Ikrar Mandiri Abadi.

Lamb, C. W., Joseph, F., Hair., \& McDaniel, C.(2001). Marketing. (David Octarevia,Trans). (Buku dua. Edisi pertama). Jakarta: Salemba Empat

Machfoedz, M. (2005). Pengantar Pemasaran Modern.Yogyakarta:UPP Akademi Manajemen Perusahaan YKPN.

Miles, M. B., Huberman, A. M., \&Saldana, J.(2014). Qualitative Data Analysis (3 ${ }^{\text {rd. ed, Tjetjep }}$ Rohindi Rohidi, Trans)USA:Sage Publications. UI-Press.

Moleong, L. J. (2014). Metodologi Penelitian Kualitatif. Bandung: Remaja Rosdakarya Moustakas, C. (2009). Phenomenological Research Methods. California: Sage Publications.

Pakpahan, E. (2014). Volume Penjualan. Jakarta: PT Bina Intitama Sejahtera.

Patton, M. Q. (2011).Metode Evaluasi Kualitatif.(Budi Puspo Priyadi, Trans).Yogyakarta: Pustaka Pelajar.

Radiosunu. (2016). Manajemen Pemasaran: Suatu Pendekatan Analisis. Yogyakarta: BPFE.

Remalya, S. A., Sunarti., \&Pangestuti, E.(2018). Analisis Strategi Promosi Dalam Upaya Meningkatkan Kunjungan Wisata Di Taman Hutan Kota (Taman Bondas) Batu. Jurnal Administrasi Bisnis (JAB),61(4),107-116.

Chandra, R. (2015). Peranan Strategi Promosi dalam Upaya Peningkatan Volume Penjualan pada Perusahaan Jasa Perhotelan, Jurnal Manajemen dan Keuangan,Vol 14, No 2.

Priyanto, R., Martina, S., Hamzah, F., Somantri, P. R., \& Syarifuddin, D. (2018) Peranan Promosi Terhadap Peningkatan Volume Penjualan Produk Rajutan di CV Konta Djaya Binong Jati, Jurnal Abdimas BS, Vol 2, No 1

Sandelowski, M. (2013). Focus on research methods: Whatever happened to qualitative description? Research in nursing \& Health. Canada: South-Western Cengage Learning. 
Amanah, S. (2015).Peranan Strategi Promosi Pemasaran Terhadap Peningkatan Volume Penjualan, Jurnal Lentera, ISSN $1693-6922$

Sugiyono. (2013). Metode Penelitian Pendidikan Pendekatan Kuantitatif, Kualitatif, dan R\&D. Bandung: Alfabeta.

Sukmadinata, N. S. (2016). Metode Penelitian Pendidikan. Bandung: Remaja Rosadakarya.

Sunarto. (2015). Manajemen Sumber Daya Manusia Strategik. Yogyakarta:

Sutojo, S., \&Kleinsteuber, F. (2002). Strategi Manajemen Pemasaran. Jakarta : PT Damar Mulia Pustaka.

Sutopo. (2011). Metodologi Penelitian Kualitatif. Surakarta: UNS.

Swastha, B., \&Irawan.(2013).Manajemen Pemasaran Modern.Yogyakarta :Liberty Yogyakarta 